\title{
Proteomic analysis of stress-related proteins in rice seeds during the desiccation phase of grain filling
}

\author{
Naoto Sano ${ }^{1,2}$, Shunpei Masaki ${ }^{1}$, Takanari Tanabata ${ }^{3}$, Tetsuya Yamada ${ }^{1}$ \\ Tadashi Hirasawa', Motoki Kanekatsu',* \\ ${ }^{1}$ Department of Plant Production, United Graduate School of Agricultural Science, Tokyo University of Agriculture and \\ Technology, Fuchu, Tokyo 183-8509, Japan; ${ }^{2}$ Research Fellow, Japan Society for the Promotion of Science, Tokyo 102-0083, \\ Japan; ${ }^{3}$ Agrogenomics Research Center, National Institute of Agrobiological Science, Tsukuba, Ibaraki 305-8602, Japan \\ *E-mail: kanekatu@cc.tuat.ac.jp Fax:+81-42-367-5733
}

Received December 11, 2012; accepted February 7, 2013 (Edited by K. Aoki)

\begin{abstract}
During seed maturation, the water content of seeds decreases remarkably. Mature seeds can germinate after imbibition since the embryos are protected by mechanism of desiccation tolerance. To better understand the mechanism of desiccation tolerance in seeds, we analyzed the fluctuation of stress-related proteins in the desiccation phase of rice seeds by a real-time RT-PCR and gel-based proteomic approach. Based on the changes in water content of developing rice seeds, we defined stages from the beginning of dehydration (10 to 20 days after flowering) and the desiccation phase (20 to 40 days after flowering). The proteomic analysis revealed that late embryogenesis abundant proteins, small heat shock proteins and antioxidative proteins accumulate at the beginning of dehydration and remain at a high level in the desiccation phase, suggesting that these proteins are involved in acquisition of desiccation tolerance. The fluctuation in levels of mRNA encoding some stress-related proteins did not precisely reflect the change in levels of these proteins. Therefore, proteomic analysis, which provides an accurate assessment of changes in protein levels, is a more efficient technique than transcriptomics for inferring the role of stress-related proteins in rice seeds.
\end{abstract}

Key words: Desiccation tolerance, Oryza sativa, plant proteomics, seed development, stress-related protein.

Seed development is initiated by a stage of morphogenesis in which the mature embryo develops from a single fertilized cell. Following morphogenesis, developing seeds enter a maturation stage, during which storage compounds are synthesized (Angelovici et al. 2010). The early and mid phases of maturation are dominated by the action of the phytohormone absciscic acid (ABA) (Nambara and Marion 2003). Subsequently, ABA levels decline and the seed enters the desiccation phase. This phase is associated with a major loss of water, and the water content of mature dry seeds is generally less than $20 \%$ on a fresh weight basis. Such severe desiccation would kill cells from vegetative parts of the plant (Jensen et al. 1996). However, these severely desiccated seeds germinate and develop into normal seedlings after imbibition, indicating that the developing seeds must acquire sufficient desiccation tolerance before the end of the desiccation phase, when their water content falls below the threshold of tolerance for vegetative cells.

Acquisition of desiccation tolerance in seeds ensures species survival under extreme environmental conditions and helps achieve wide dispersal of the seeds. The tolerance of the seed also allows the embryo to maintain viability over remarkably long periods, ranging over centuries or even millennia (Sallon et al. 2008), whereas some economically important plants have recalcitrant seeds, which are sensitive to desiccation and cannot be stored for long periods (Angelovici et al. 2010). Therefore, an accurate understanding of the events in seed desiccation and clarification of the mechanisms of desiccation tolerance are important for agriculture. However, little is known about how seed viability is retained under severe desiccation.

Mature seeds contain several kinds of stress-related proteins which were induced in vegetative parts of the plant under various stress conditions such as dehydration, osmotic stress, salinity, flooding, heat and cold stress (Cuming 1999; Mittler 2002; Sarkar et al. 2009). Thus, some of these stress-related proteins in mature seeds might be implicated in the desiccation tolerance of seeds. To identify stress-related proteins

Abbreviations: ABA, absciscic acid; DAF, days after flowering; HSPs, heat shock proteins; LEA, late embryogenesis abundant; ROS, reactive oxygen species; RBPs, RNA-binding proteins

This article can be found at http://www.jspcmb.jp/

Published online June 15, 2013 
with important functions in desiccation tolerance of rice seeds, analysis of alterations in these proteins during seed formation in association with a decrease in seed water content is required.

The analysis of mRNA abundance is an effective approach for assessing fluctuations in expression of gene products. In the case of rice, some microarray gene expression data analyzing fluctuations in mRNA abundance are available online. Moreover, quantitative real-time RT-PCR is a commonly used validation tool for confirming gene expression results obtained from microarray analysis (Morey et al. 2006). Although realtime RT-PCR is efficient for analysis of gene expression, the correlation coefficient between mRNA and protein abundance is only about 0.5 (Anderson and Seilhamer 1997; Yan et al. 1999). Gygi et al. (1999) reported that the correlation between mRNA and protein levels was insufficient to predict protein expression levels from quantitative mRNA data in yeast. In order to obtain an accurate understanding of altered gene expression in stress-related proteins during seed formation, it is important to analyze their accumulation both at the mRNA and protein levels. Proteomics is an effective strategy for global analysis of protein fluctuations. However, proteomic approaches have been employed in only a few studies of developing rice seeds (Lee and Koh 2011; Xu et al. 2008; Xu et al. 2012). One benefit of gel-based proteomics is that it is simple to determine the amount of proteins and to characterize protein isoforms such as post-translational modifications and spliced forms of the same gene or protein (Chevalier 2010).

In this study, the fluctuation of stress-related proteins in the desiccation phase of rice seeds were examined by real-time RT-PCR and a gel-based proteomic approach to identify proteins that play important roles in desiccation tolerance. We also compare the efficiency of proteomic and transcriptomic techniques in analysis of the function of stress-related proteins in rice seeds.

\section{Materials and methods}

\section{Plant materials and sampling}

Rice (Oryza sativa L. cv. Nipponbare) plants were cultured during the rice growing season (May to September) under natural conditions in Tokyo. Spikelets were tagged on the day of female anthesis, and harvested at $0,5,10,20,30$, and 40 days after flowering (DAF).

\section{Determination of water content of developing seed}

Dry weight (DW) of developing seeds was measured gravimetrically after drying the 100 seeds in each stage at 0,5 , $10,20,30$ and $40 \mathrm{DAF}$ in an oven at $80^{\circ} \mathrm{C}$ for $24 \mathrm{~h}$. The water content (\%) of seeds at each stage was defined as $100 \times(\mathrm{FW}-$ DW)/FW. The reported values are means \pm SE for three replicates.

\section{Extraction of RNA from developing seed}

Twenty dehulled seeds in each stage at 10, 20, 30 and 40 DAF were homogenized in Fruit-mate for RNA Purification (TaKaRa Bio Inc., Japan) and centrifuged at $12,000 \times g$ at $4^{\circ} \mathrm{C}$ for $5 \mathrm{~min}$. The total RNA was isolated from the supernatant using RNAiso Plus reagent (TaKaRa Bio Inc.) according to the manufacturer's instructions. The quantity and quality of extracted RNA was assessed at wavelengths of 230, 260, and $280 \mathrm{~nm}$ using a Nano Drop 1000 spectrophotometer (Thermo Fisher Scientific, USA).

\section{Real-time RT-PCR analysis}

cDNA was prepared from $1 \mu \mathrm{g}$ of each RNA sample using the PrimeScript RT reagent kit with gDNA Eraser (TaKaRa Bio Inc.). Real-time RT-PCR analysis was performed using the EXPRESS SYBR GreenER qPCR Super Mix Universal (Invitrogen, USA) and a StepOnePlus system (Applied Biosystems, USA). Primers for real-time RT-PCR were designed from the sequence of target genes using Primer3 software (http://frodo.wi.mit.edu) for products ranging in size between 100 and $250 \mathrm{bp}$, a primer size of $20 \mathrm{bp}$, and a primer $\mathrm{Tm}$ of $62^{\circ} \mathrm{C}$, and are listed in Supplementary Table 1 . The constitutively expressed gene Actin 1 (AK100267, Li et al. (2010)) was used as an internal standard. Three separate experiments were carried out to ensure the reliability of the results.

\section{Extraction of protein from developing seed}

Fifty dehulled seeds in each stage at 10, 20, 30 and 40 DAF were homogenized with a homogenizer in $5 \mathrm{ml}$ of extraction buffer [50 mM Tris/HCl (pH 7.4), $1 \mathrm{mM}$ EDTA, $10 \mathrm{mM}$ 2-mercaptoethanol, $0.1 \mathrm{mM} \mathrm{MgCl}_{2}, 0.1 \mathrm{mM}$ PMSF and $10 \%$ $(\mathrm{w} / \mathrm{v})$ glycerol] containing $1.5 \mathrm{M} \mathrm{KCl}$ and centrifuged at $22,000 \times \mathrm{g}$ at $4^{\circ} \mathrm{C}$ for $30 \mathrm{~min}$. The supernatant was concentrated and protein precipitated with a mixture of methanol/ chloroform using the method of Wessel and Flügge (1984). The pellet was resuspended in $200 \mu$ l lysis buffer [ $8 \mathrm{M}$ urea, $4 \%$ (w/v) CHAPS, $0.8 \%$ (v/v) IPG buffer (GE Healthcare, England), 1\% $(\mathrm{w} / \mathrm{v})$ dithiothreitol].

\section{2-DE analysis}

First-dimension IEF separation was performed using gel strips forming an immobilized linear $\mathrm{pH}$ gradient from 3 to 10 (Immobiline DryStrip, $13 \mathrm{~cm}$, GE Healthcare). The strips were loaded with protein samples and rehydrated for $12 \mathrm{~h}$ at $20^{\circ} \mathrm{C}$ on an IPGphor system (GE Healthcare). IEF was performed as follows: $1 \mathrm{~h}$ at $500 \mathrm{~V}, 1 \mathrm{~h}$ at $1,000 \mathrm{~V}$, and $13 \mathrm{~h}$ at $8,000 \mathrm{~V}$. The strips were equilibrated for $20 \mathrm{~min}$ in equilibration buffer [50 mM Tris-HCl (pH 8.8), 6 M urea, 30\% (w/v) glycerol, $2 \%$ $(\mathrm{w} / \mathrm{v})$ SDS, and $0.01 \%(\mathrm{w} / \mathrm{v})$ bromophenol blue] containing $10 \mathrm{mg} \mathrm{DTT} / \mathrm{ml}$. Second-dimension SDS-PAGE separation was performed using a $15 \%$ polyacrylamide gel. Polypeptide spots were visualized using Coomassie Brilliant Blue staining solution $[0.25 \%(\mathrm{w} / \mathrm{v})$ CBB R-250, 15\% (v/v) acetic acid and 
Table 1. Identification of stress-related proteins in mature seeds of rice.

\begin{tabular}{|c|c|c|c|c|c|c|c|c|c|}
\hline \multirow{2}{*}{ Spot No. ${ }^{\text {a }}$} & \multirow{2}{*}{ Protein name } & \multicolumn{2}{|c|}{$\mathrm{p} I^{\mathrm{b}}$} & \multicolumn{2}{|c|}{$\operatorname{Mr}(\mathrm{kDa})^{\mathrm{c}}$} & \multirow{2}{*}{ Score $^{\mathrm{d}}$} & \multirow{2}{*}{$\begin{array}{c}\text { Cov. }^{\mathrm{e}} \\
(\%)\end{array}$} & \multirow{2}{*}{$\begin{array}{l}\text { Pept. } \\
\text { Match }\end{array}$} & \multirow{2}{*}{ Accession No. ${ }^{\mathrm{g}}$} \\
\hline & & Exp. & Theo. & Exp. & Theo. & & & & \\
\hline 1 & $\begin{array}{l}18.1 \mathrm{kDa} \text { heat shock } \\
\text { protein }\end{array}$ & 5.9 & 5.8 & 19.6 & 17.9 & 75 & 27 & 3 & LOC_Os03g15960 \\
\hline 2 & $\begin{array}{l}16.9 \mathrm{kDa} \text { heat shock } \\
\text { protein }\end{array}$ & 6.3 & 6.2 & 18.2 & 16.9 & 85 & 42 & 5 & LOC_Os01g04370 \\
\hline $3 a$ & $70 \mathrm{kDa}$ heat shock protein & 4.9 & 5.1 & 81.5 & 74.3 & 84 & 13 & 6 & LOC_Os12g14070 \\
\hline $3 b$ & & 4.8 & & 81.0 & & 85 & 13 & 7 & \\
\hline 4 & glyoxalase I & 5.6 & 5.5 & 39.5 & 32.9 & 72 & 38 & 5 & LOC_Os08g09250 \\
\hline 5 & $\begin{array}{l}\text { putative stress-induced } \\
\text { protein stil }\end{array}$ & 6.4 & 6.0 & 59.8 & 64.9 & 102 & 16 & 7 & LOC_Os02g43020 \\
\hline 6 & peroxiredoxin & 6.6 & 6.0 & 30.2 & 24.0 & 152 & 57 & 5 & LOC_Os07g44430 \\
\hline $7 \mathrm{a}$ & putative aldose reductase & 6.7 & 6.3 & 39.4 & 35.6 & 132 & 42 & 7 & LOC_Os05g39680 \\
\hline $7 b$ & & 6.3 & & 33.1 & & 72 & 30 & 4 & \\
\hline 8 & $\begin{array}{l}\text { putative embryonic } \\
\text { abundant protein, } \\
\text { group } 3\end{array}$ & 6.3 & 6.1 & 34.2 & 24.5 & 79 & 31 & 4 & LOC_Os01g16920 \\
\hline 9 & $\begin{array}{l}\text { late embryogenesis } \\
\text { abundant protein } 1\end{array}$ & 6.6 & 6.4 & 43.8 & 36.8 & 89 & 25 & 5 & LOC_Os03g20680 \\
\hline $10 \mathrm{a}$ & putative embryo-specific & 7.3 & 8.3 & 44.8 & 41.8 & 71 & 26 & 9 & LOC_Os03g07180 \\
\hline $10 \mathrm{~b}$ & protein & 7.4 & & 44.8 & & 87 & 26 & 9 & \\
\hline $10 c$ & & 7.5 & & 44.0 & & 70 & 25 & 9 & \\
\hline 11 & $\begin{array}{l}\text { putative } 20 \mathrm{kDa} \\
\text { chaperonin }\end{array}$ & 5.1 & 6.0 & 35.2 & 25.5 & 87 & 31 & 4 & LOC_Os09g26730 \\
\hline 12 & $\begin{array}{l}\text { putative chaperonin } 21 \\
\text { precursor }\end{array}$ & 5.7 & 7.7 & 34.2 & 26.3 & 102 & 38 & 6 & LOC_Os06g09679 \\
\hline
\end{tabular}

${ }^{a}$ Consistent with the spot numbers in Figure 2. ${ }^{\mathrm{b}} \mathrm{p} I$ Exp. is experimental isoelectric point, Theo. is theoretical isoelectric point. ${ }^{\mathrm{c}} \mathrm{Mr}$ (kDa) Exp. is experimental molecular size, Theo. is theoretical molecular size. ${ }^{\mathrm{d}}$ The protein score is $-10 * \log (\mathrm{P})$, where $\mathrm{P}$ is the probability that the observed match is a random event. Protein scores greater than 64 are significant $(p<0.05) .{ }^{e}$ Sequence coverage $(\%) .{ }^{f}$ Number of matched peptides. ${ }^{g}$ Accession number of the matched protein in the MSU Rice Genome Annotation (http://rice.plantbiology.msu.edu/).

$45 \%(\mathrm{v} / \mathrm{v})$ methanol]. The processes of protein extractions and 2-DE analyses were repeated three times to ensure the reliability of the results. Quantitative changes detected in images of the spot pattern of 2-DE gels were analyzed using software we developed, Polyans2D, provided as freeware at http://www. kazusa.or.jp/polyans2d. Relative protein levels were determined by comparing protein spot intensities to the intensity of a marker protein [approximately $1.5 \mu \mathrm{g}$ of ovalbumin in the SDS-PAGE Molecular Weight Standards, Low Range (Bio-Rad, USA)].

\section{In-gel digestion and MALDI-TOF-MS analysis}

Proteins were identified by peptide mass fingerprinting using MALDI-TOF-MS. Protein spots were excised from Coomassiestained gels and destained for $20 \mathrm{~min}$ at $25^{\circ} \mathrm{C}$ in $100 \mathrm{mM}$ $\left(\mathrm{NH}_{4}\right)_{2} \mathrm{CO}_{3}$ in $50 \%(\mathrm{v} / \mathrm{v})$ acetonitrile, then dried by vacuum centrifugation. Dried gel pieces were treated with reducing solution [ $25 \mathrm{mM}\left(\mathrm{NH}_{4}\right)_{2} \mathrm{CO}_{3}$ in $\left.10 \mathrm{mM} \mathrm{DTT}\right]$ for $60 \mathrm{~min}$ at $56^{\circ} \mathrm{C}$ followed by alkylation solution $\left[25 \mathrm{mM}\left(\mathrm{NH}_{4}\right)_{2} \mathrm{CO}_{3}\right.$ in $1 \%$ (w/v) iodoacetamide]. The gel pieces were washed with $100 \%$ acetonitrile and dried by vacuum centrifugation, then digested overnight at $37^{\circ} \mathrm{C}$ with sequencing grade modified trypsin (Promega KK, Japan). The resulting peptides were purified with a ZipTip C18 pipette tip (Millipore, USA) and mixed with $1 \mu \mathrm{l}$ of $\alpha$-cyano-4-hydroxycinnamic acid. Peptide masses were determined using a Voyager-DE STR workstation (Applied
Biosystems). The resulting monoisotopic peptide masses were matched to the NCBInr database using the Mascot sequence database search program at http://www.matrixscience.com. The search parameters allowed for one missed cleavage, and variable modifications of methionine oxidation and cysteine carboxyamidomethylation with a peptide mass tolerance of $100 \mathrm{ppm}$. Protein identifications were accepted if protein score is higher than 64 (significance threshold of $p<0.05$ on NCBInr), the number of matched peptides is not less than two, and the sequence coverage is over $12 \%$ in Mascot search results.

\section{Results}

\section{Morphological features and changes in water content of developing seeds}

To determine the desiccation phase during seed development in rice, the water content and morphological features of developing seed at $0,5,10$, 20, $30 \mathrm{DAF}$ and of mature seed (40 DAF) were analyzed (Figure 1). At $0 \mathrm{DAF}$, the water content on a fresh weight basis of developing seed was about $60 \%$ and the value remained unchanged by 10 DAF (Figure $2 \mathrm{~B}$ ). In this period, the developing seed greatly increased in size (Figure 1A). After flowering, the fertilized egg cell of rice undergoes fast cell division and differentiation, which leads to the formation of the embryo; the embryo 


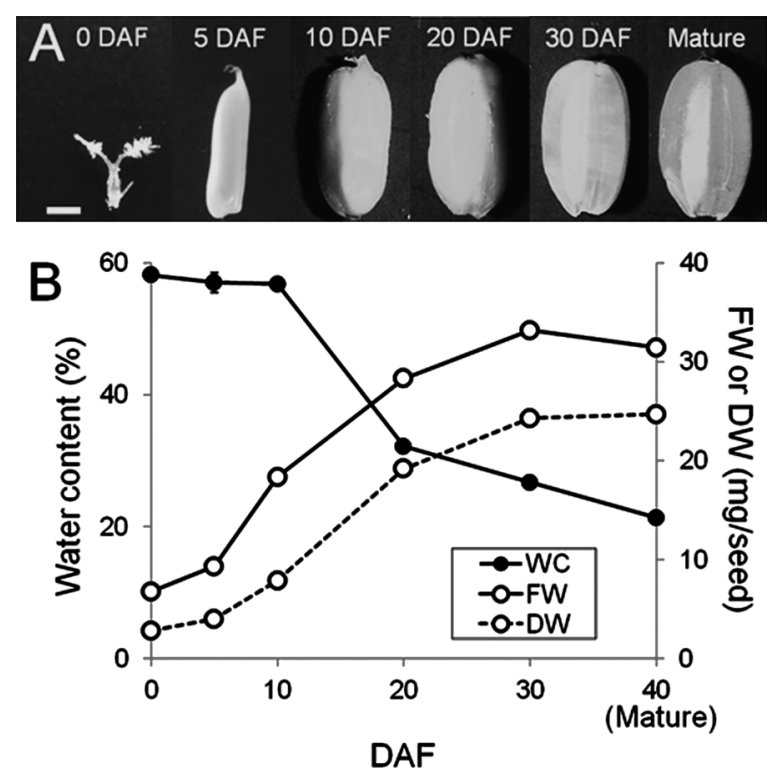

Figure 1. Changes in morphological feature and water content of developing rice seeds. (A) Photographs show dehulled rice seeds during development at 0, 5, 10, 20, 30 and 40 DAF. Bar $=1 \mathrm{~mm}$. (B) Changes in fresh weight (FW), dry weight (DW) and water content (WC) of developing seeds. Values are means of three replicates \pm SE.

reaches maturity at approximately 10 DAF (Ishimaru et al. 2003). For endosperm development, the fertilized polar nuclei undergo numerous cycles of mitosis without cellularization until 3 DAF. The cellularization of endosperm begins at $3 \mathrm{DAF}$ and ceases at 6 to 7 DAF. Therefore, the period from 0 to $10 \mathrm{DAF}$ is a stage of morphogenesis when the seeds have a relatively high water content.
After 10 DAF, the water content of the developing seed dropped markedly, to a value of $32 \%$ by 20 DAF (Figure $1 \mathrm{~B})$, indicating that this period is the beginning stage of dehydration. At the same time, the fresh and dry weight of the developing seed increased remarkably from 10 to 20 DAF (Figure 1B). Developing rice seeds typically reach mature size at about $12 \mathrm{DAF}$, and thereafter the endosperm enters the storage and desiccation phase.

The loss of water was not complete at $20 \mathrm{DAF}$, and the water content decreased gradually to $27 \%$ by $30 \mathrm{DAF}$ and reached $21 \%$ in the mature seed (40 DAF) (Figure 1B). Hoekstra et al. (2001) reported that desiccation tolerance can be considered as tolerance to dehydration down to a moisture content below $23 \%$ water on a fresh weight basis, which means that developing seeds must acquire sufficient desiccation tolerance before 40 DAF, when their water content drops below the threshold of tolerance. Therefore, the period from 20 to $40 \mathrm{DAF}$ during rice seed formation is generally referred to as a desiccation phase, which is an almost completed stage of dehydration and must provide the seed with the ability to survive severely desiccated conditions.

\section{Identification of stress-related proteins in mature rice seeds}

In order to detect stress-related proteins involved in desiccation tolerance in mature seeds, a gel-based proteomic analysis of seeds at $40 \mathrm{DAF}$ was carried out. Total protein was extracted from mature seeds and then separated by two-dimensional gel electrophoresis (2DE) (Figure 2). By peptide mass fingerprinting analysis, 44 proteins could be identified in the 2-DE gel (Figure

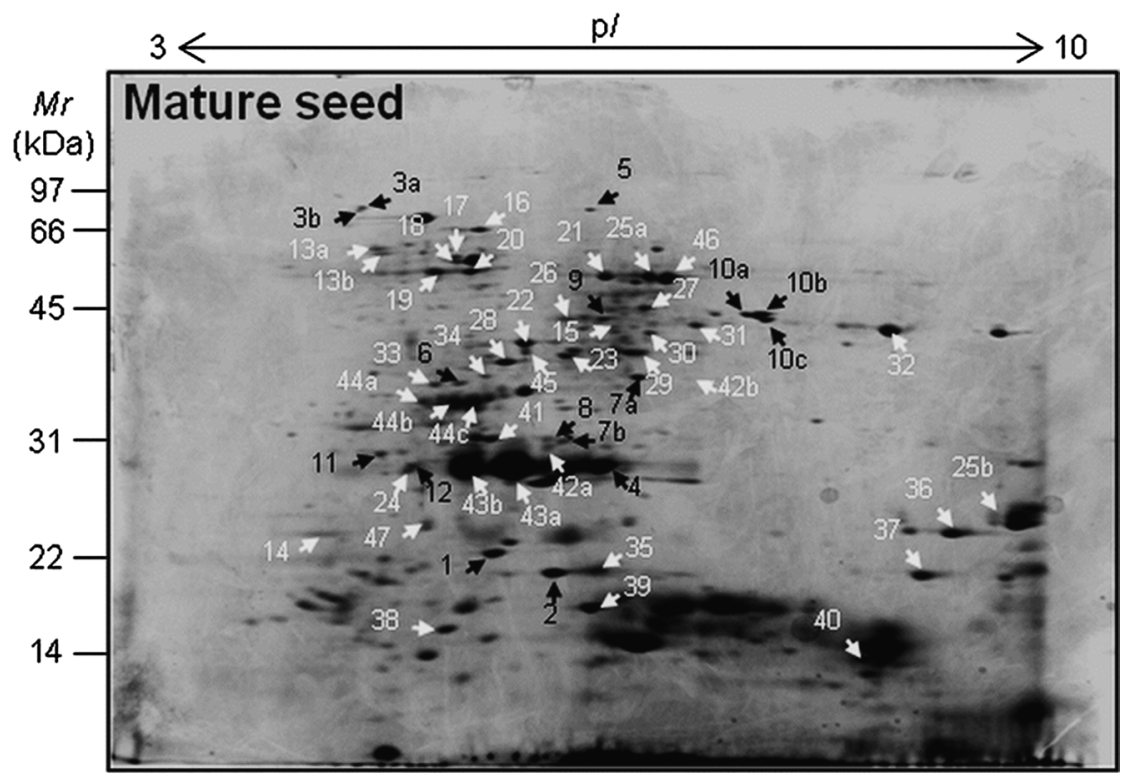

Figure 2. Detection of stress-related proteins in mature seeds of rice by 2-DE analysis. Total protein extracted from 100 dehulled seeds at $40 \mathrm{DAF}$ was separated by IEF using Immobiline DryStrip gels ( $\mathrm{pH}$ 3-10) followed by SDS-PAGE (15\% gels). Proteins were stained with Coomassie Brilliant Blue. Arrows indicate spots that were identified using MALDI-TOF-MS. Black arrows identify the proteins involved in stress response. Proteins involved in other functions are indicated by white arrows. 
2, Supplementary Table 2). Of these 44 proteins, 12 proteins in all were apparently involved in responses to various environmental stresses (Table 1). Moreover, these stress-related proteins could be classified into three major groups according to their physiological functions: molecular chaperones, antioxidative proteins and late embryogenesis abundant (LEA) proteins.

Six of the 12 stress-related proteins are concerned with molecular chaperones that facilitate the native folding of proteins and play an important role during stress by preventing irreversible aggregation of denatured proteins (Sarkar et al. 2009). The $18.1 \mathrm{kDa}$ heat shock protein (HSP) (spot 1), $16.9 \mathrm{kDa}$ HSP (spot 2) and $70 \mathrm{kDa}$ HSP (spots $3 \mathrm{a}, 3 \mathrm{~b}$ ) play roles as molecular chaperones in the heat shock response. A protein identified as a putative stress-induced protein, stil (spot 5), contains two heat shock chaperonin-binding motifs (STI1) and three tetratricopeptide repeat. The function of tetratricopeptide repeat-containing proteins is mediated through protein-protein interaction to modulate diverse cellular processes, including HSP 90 signaling and interaction (Flom et al. 2006). A $20 \mathrm{kDa}$ putative chaperonin (spot 11) and chaperonin 21 precursor (spot 12) are presumably chloroplast co-chaperonins, composed of two chaperonin 10-like domains, that are involved in heat shock stress (Viitanen et al. 1995).

Three proteins were identified as antioxidative proteins. These proteins are involved in the suppression of the production of reactive oxygen species (ROS) that attack DNA, proteins and membranes, causing lipid peroxidation and deesterification (Potts 1994). Levels of the deleterious ROS are enhanced when the metabolic balance of cells is disrupted by abiotic stresses (Mittler 2002). Glyoxalase I (spot 4) is associated with detoxification of methylglyoxal, a cytotoxic $\alpha$-ketoaldehyde by-product of glycolysis (Mustafiz et al. 2011). Peroxiredoxin (spot 6) is a thiol-dependent antioxidant, containing one conserved cysteine residue, that protects lipids, enzymes, and DNA against ROS (Haslekås et al. 2003). Putative aldose reductase (spots $7 \mathrm{a}$ and $7 \mathrm{~b}$ ) plays a key role in detoxification of biogenic and xenobiotic aldehydes to their corresponding alcohols (Sree et al. 2000).

Spots 8, 9, 10a, 10b and 10c were identified as LEA proteins, which are abundant in the seeds of many higher plants and probably occur universally in plant seeds. LEA protein expression can be induced at other stages in plants by desiccation stress or by treatment with ABA (Cuming 1999).

\section{Changes in transcript abundance of stress-related proteins during seed desiccation}

The 12 stress-related proteins detected in mature dry seeds may have important roles in desiccation tolerance during rice seed maturation. To clarify this point, an analysis of the relationship between seed water content and accumulation of these proteins is essential. The amounts of proteins involved in acquisition of desiccation tolerance probably increase from 10 to 20 DAF, when the dramatic loss of water in seeds begins. Moreover, the proteins involved in desiccation tolerance are expected to be present in seeds at the 20 to 40 DAF stage of nearly complete dehydration. Therefore, changes in the transcript abundance of these 12 stress-related proteins during seed formation were analyzed using realtime RT-PCR.

Transcripts of chloroplast co-chaperonins (spots 11 and 12) were constitutively existed from 10 to $40 \mathrm{DAF}$ (Figure 3). On the other hand, the transcripts of the other 10 stress-related proteins were up-regulated from 10 to 20 DAF, when seeds showed significant loss of water. Thus, the increased transcript levels for these 10 proteins coincide with the beginning of dehydration. At the desiccation phase from 20 to $40 \mathrm{DAF}$, only transcript levels of LEA proteins (spots 8, 9, and 10a, $10 \mathrm{~b}, 10 \mathrm{c}$ ) continued to increase (Figure 3). Transcripts of peroxiredoxin (spot 6) and putative aldose reductase (spots $7 \mathrm{a}, 7 \mathrm{~b}$ ), were maintained at a high level until 40 DAF (Figure 3), suggesting that these proteins may play important roles in the desiccation phase. In contrast, transcripts of HSPs (spots 1, 2, and 3a, 3b) were remarkably down-regulated at 30 to 40 DAF (Figure 3). Similar results were obtained for glyoxalase I (spot 4) and putative stress-induced protein stil (spot 5), but their accumulation patterns did not fluctuate as much as those of HSPs. The analysis of transcripts by real-time RT-PCR revealed that HSPs, glyoxalase I and stil may not be required for desiccation tolerance after 20 DAF. However, the mRNA abundance might not correspond with the expression of these stress-related proteins.

\section{Changes in protein abundance of stress-related proteins during seed desiccation}

A gel-based proteomic analysis of developing rice seed after the beginning of water loss at 10 DAF was carried out to detect proteins associated with desiccation tolerance. Figure 4 shows quantitative changes in stressrelated proteins in 2-DE gels during desiccation.

Real-time RT-PCR demonstrated that the transcripts of LEA proteins (spots 8, 9, and 10a, 10b, 10c), peroxiredoxin (spot 6) and putative aldose reductase (spots $7 \mathrm{a}, 7 \mathrm{~b}$ ) are accumulated at high levels in seeds both at the beginning of dehydration and during desiccation. In accordance with the changes in transcripts, the abundance of LEA proteins continuously increased from 10 to 40 DAF (Figure 5). A similar upregulation of peroxiredoxin and a putative aldose reductase was also detected (Figure 5), although upregulation of the corresponding transcripts peaked at $20 \mathrm{DAF}$ (Figure 3). Therefore, the possibility that 


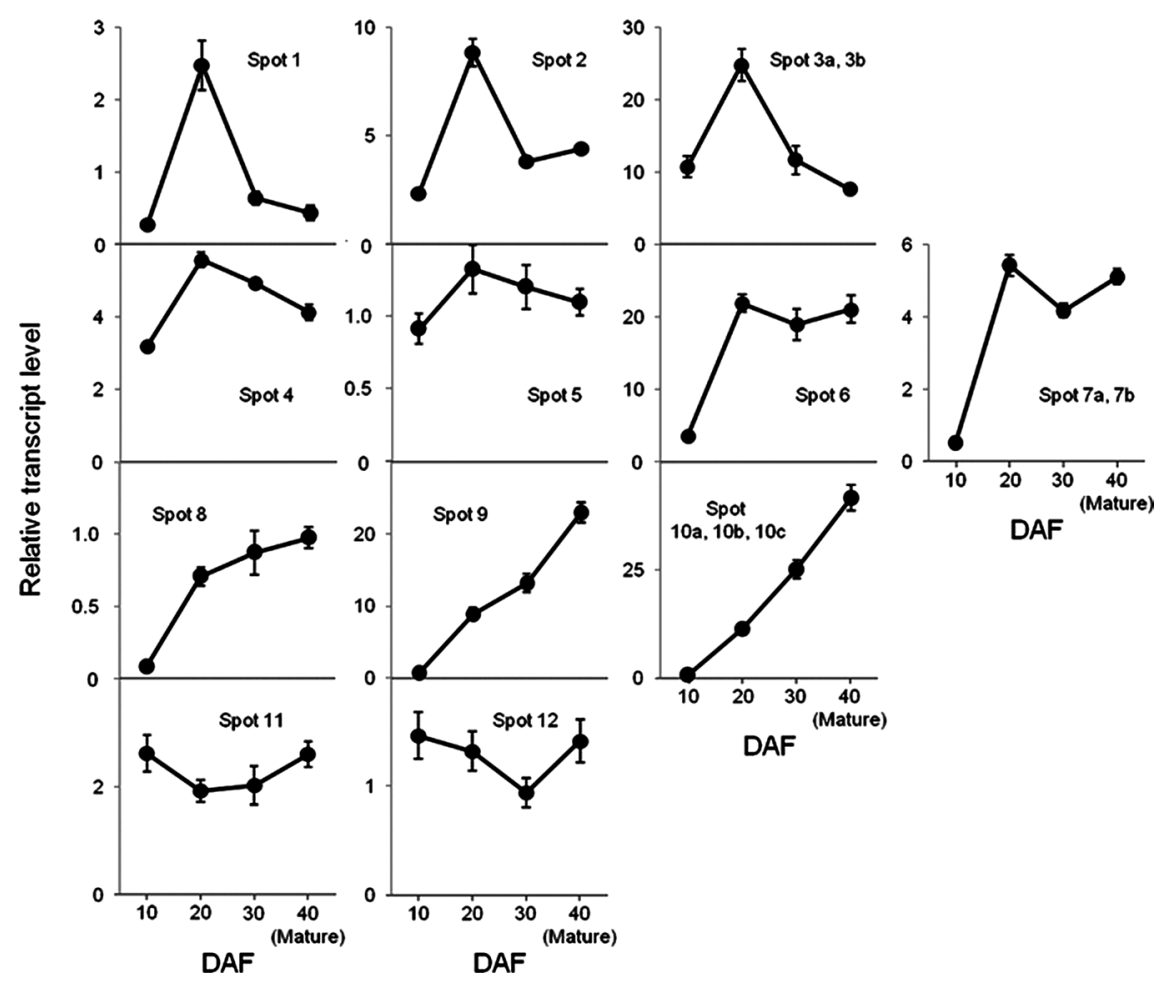

Figure 3. Changes in relative transcript levels of stress-related proteins during seed desiccation. Data were obtained by real-time RT-PCR and are shown as means of three replicates \pm SE determined at 10, 20,30 and 40 DAF using Actin 1 as an internal standard.

these proteins are strongly associated with desiccation tolerance of developing rice seeds was supported by a proteomic method.

Quantitative changes in five stress-related proteins, the three HSPs, glyoxalase I and sti 1, which had peak transcript abundance at 20 DAF (Figure 3), were also analyzed. Among the HSPs, only the change in the amount of the $70 \mathrm{kDa}$ HSP (spots $3 \mathrm{a}, 3 \mathrm{~b}$ ) accorded well with transcript levels (Figure 3), since the protein was up-regulated from 10 to 20 DAF and remarkably downregulated from 20 to 40 DAF (Figure 5). This indicates that the $70 \mathrm{kDa}$ HSP may play an important role at the beginning of dehydration but not during desiccation. In contrast, the alteration in amounts of the other two HSPs (spots 1 and 2) did not correspond with their mRNA levels. The abundance of these proteins continuously increased from 10 to 40 DAF (Figure 5) despite a decreased transcript abundance at 30 to 40 DAF (Figure 3). This observation suggests that these small HSPs may be required in the desiccation phase as well as at the beginning of dehydration. The changes in abundance of glyoxalase I (spot 4) did not agree with those of its transcript. Although the mRNA level for this enzyme peaked at 20 DAF (Figure 3), no translational product could be detected then (Figure 5). Glyoxalase I became detectable in 2-DE gels after $30 \mathrm{DAF}$ and continued to increase through 40 DAF (Figure 5). Thus, glyoxalase I may play an important role in the desiccation phase of rice seeds between 30 and $40 \mathrm{DAF}$. On the other hand, the amount of sti 1 (spot 5) did not fluctuate from 10 DAF to 40 DAF (Figure 5) and was not in accord with the change in its mRNA abundance (Figure 3). The chloroplast co-chaperonins (spots 11 and 12) were constitutively accumulated from 10 to 40 DAF (Figure 5 ) as were their transcripts (Figure 3). These results indicate that the accumulation of sti 1 and chloroplast cochaperonins does not depend on the change of the water content.

\section{Discussion}

Stress-related proteins implicated in the desiccation tolerance of rice seeds

Based on the changes in water content of developing rice seeds, we defined the stages for the beginning of dehydration (10 to $20 \mathrm{DAF}$ ) and the desiccation phase (20 to $40 \mathrm{DAF}$ ) of seed formation (Figure 1). Based on proteomic analysis, the levels of LEA proteins, small HSPs and antioxidant proteins were up-regulated at the beginning of dehydration and during desiccation (Figure 5). This evidence supports the involvement of these stress-related proteins in desiccation tolerance in developing rice seeds. Moreover, we analyzed transcripts of these stress-related proteins quantitatively. However, the fluctuation in the mRNAs of small HSPs and glyoxalase I was quite different from that in their protein levels (Figures 3, 5). Therefore, quantitative analysis of transcripts may not always reflect changes 


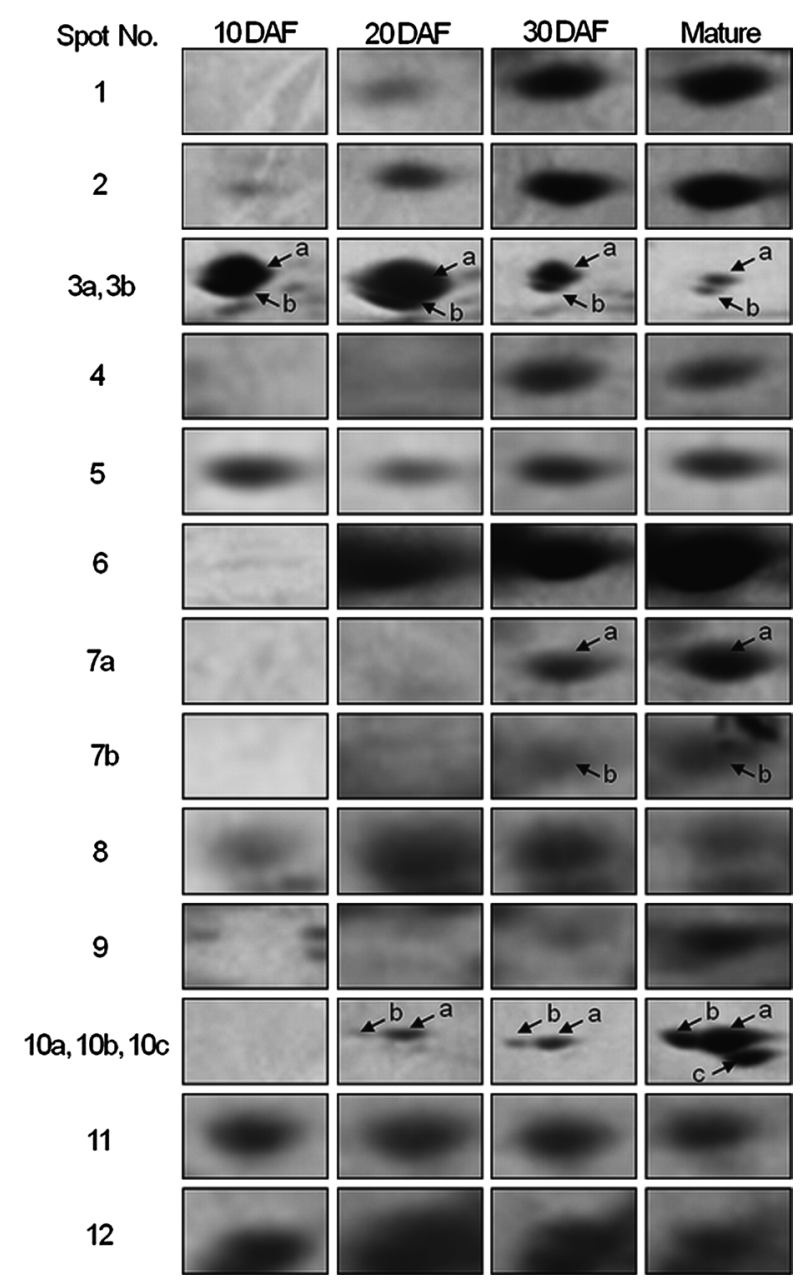

Figure 4. Quantitative changes in stress-related proteins. Total protein extracted from 100 dehulled seeds at 10, 20, 30 and 40 DAF was separated by IEF using Immobiline DryStrip gels ( $\mathrm{pH} 3-10)$ followed by SDS-PAGE (15\% gels). Proteins were stained with Coomassie Brilliant Blue and images were acquired of the 2-DE gels. Arrows indicate isoforms of three stress-related proteins (spots 3, 7 and 10).

in rice seed proteins. To infer the function of the gene products, proteomic analysis, which provides an accurate assessment of fluctuations in protein levels, is a more efficient technique.

\section{The roles of $L E A$ proteins in the desiccation tolerance of rice seeds}

LEA proteins and oligosaccharides have been proposed to participate in glass formation (Kalemba and Pukacka 2007). During water loss, desiccation-tolerant organisms have the ability to form intracellular glass using an oligosaccharide matrix. The glass structure assures cell stability at the time of dehydration, since the high viscosity of glass can prevent the crystallization of chemical compounds, membrane fusion, and conformational changes of proteins (Hoekstra et al. 2001). Still et al. (1994) reported that in developing embryos of rice seeds, sucrose is accumulated linearly from 10 to 40 DAF and this accumulation pattern paralleled the increase we observed in LEA proteins (Figure 5). Using synthetic models, Shimizu et al. (2009) reported that LEA proteins are intrinsically disordered in solution but fold into $\alpha$-helices during drying, and these proteins play a role in reinforcing the glassy matrix of oligosaccharides. Therefore, LEA proteins and their proposed role in ensuring a glassy state may be essential for rice seeds to acquire desiccation tolerance.

\section{The roles of HSPs in the desiccation tolerance of rice seeds}

According to their approximate molecular weights, HSPs are grouped into five families: HSP100s, HSP90s, HSP70s, HSP60s, and small HSPs smaller than $40 \mathrm{kDa}$ (Trent 1996). Not only in response to heat stress, some HSPs are synthesized in other stresses. For example, the proteins are induced by drought stress, just as LEA proteins and their synthesis seem to coincide with the acquisition of desiccation tolerance in plants (Wehmeyer et al. 1996). Zou et al. (2009) reported finding more than 70 putative HSP genes in the Rice Genome Annotation Project database (http://rice.plantbiology.msu.edu). However, the HSPs required for desiccation tolerance in rice seeds have been unclear.

We identified two small HSPs (an $18.1 \mathrm{kDa}$ HSP, spot 1 , and a $16.9 \mathrm{kDa}$ HSP, spot 2) and an HSP70 $(70 \mathrm{kDa}$ HSP, spots $3 \mathrm{a}, 3 \mathrm{~b}$ ) from mature seeds of rice (Table 1). The fluctuation in amounts of these two types of HSPs was entirely different (Figure 5). The amount of the two small HSPs continuously increased from 10 to 40 DAF (Figure 5). The LEA-like protein small HSP12 is associated with preservation of membranes during desiccation in yeast cells (Sales et al. 2000). Moreover, in Arabidopsis seeds, Wehmeyer and Vierling (Wehmeyer et al. 1996) showed that a small HSP is much reduced in desiccation-sensitive mutant seeds of abi3-6, fus33, lec1-2, and line24 compared to wild type. Hence, the two small HSPs in rice seeds may be required for acquisition of desiccation tolerance both at the beginning of dehydration and in the desiccation phase of seed formation.

In contrast, the amount of $70 \mathrm{kDa}$ HSP was upregulated from 10 to $20 \mathrm{DAF}$ and remarkably downregulated from 20 to 40 DAF (Figure 5). A $70 \mathrm{kDa}$ HSP is up-regulated in rice seedlings treated with $\mathrm{ABA}$ (Zou et al. 2009). In addition, drought tolerance is increased by overexpression of a tobacco HSP70 (Cho and Hong 2006). Therefore, $70 \mathrm{kDa}$ HSP in rice seeds may play an important role in the acquisition of desiccation tolerance, but only at the beginning of dehydration.

The roles of antioxidant proteins in the desiccation tolerance of rice seeds

During dehydration, the membrane architecture of the cells of organisms becomes fluidized and perturbed. 


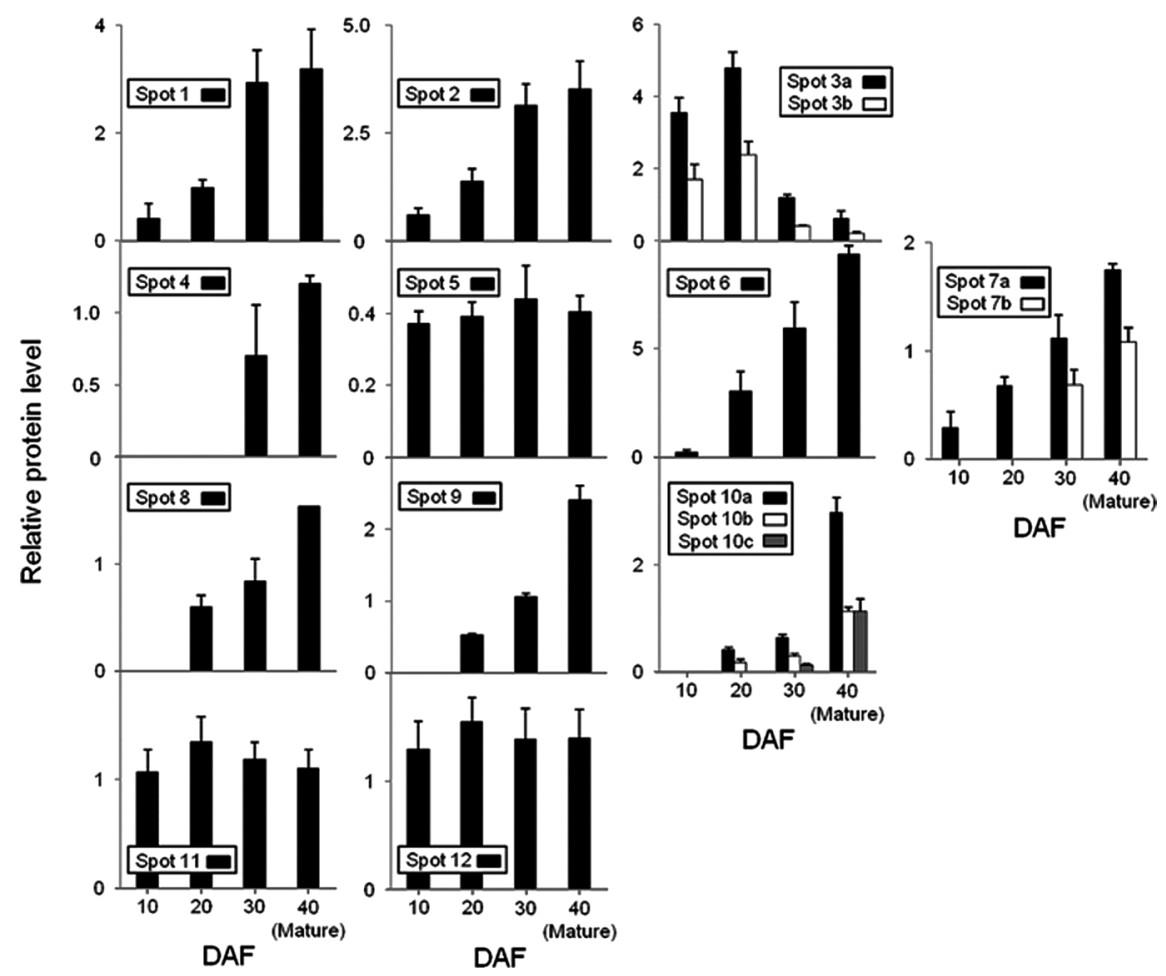

Figure 5. Changes in relative levels of stress-related proteins during seed desiccation phase. Relative protein levels were calculated by Polyans $2 \mathrm{D}$ software using an ovalbumin marker protein in 2-DE gels as an internal control. Values are means of three replicates \pm SE determined at 10, 20, 30 and 40 DAF.

Membrane perturbation might be the cause of impairment of the electron transport chain, which is thought to lead to increased formation of ROS (Hoekstra et al. 2001). In seed development, ROS are continuously produced and have a dual role; at low concentrations, they act as messengers in cellular signaling pathways related to germination or dormancy, whereas they are toxic at high concentrations, causing cellular alterations and damage (Bailly et al. 2008). In order to control the effects of deleterious ROS, plants have antioxidant enzymes such as superoxide dismutase, ascorbate peroxidase, catalase, peroxidase, glyoxalase, aldehyde reductases and peroxiredoxin (Farrant and Moore 2011; Mittler et al. 2004; Mustafiz et al. 2010). We observed peroxiredoxin and a putative aldose reductase at the beginning of dehydration in rice seed, and the amounts of these proteins continued to increase in the desiccation phase (Figure 5). Furthermore, glyoxalase I was specifically accumulated in the later stage of desiccation (Figure 5). Thus, peroxiredoxin, a putative aldose reductase and glyoxalase I may function in acquisition of desiccation tolerance by reducing the levels of deleterious ROS at the stages when they were detected. To understand how levels of ROS are controlled during maturation of rice seeds, it will be important to analyze these three enzymes biochemically.
Comparison of fluctuation in gene expression at the protein and mRNA levels of stress-related proteins during seed desiccation

The transcripts of small HSPs and glyoxalase I showed transient accumulation at 20 DAF (Figure 3), whereas the proteins were clearly up-regulated even after $30 \mathrm{DAF}$ (Figure 5). Additionally, up-regulation of peroxiredoxin and putative aldose reductase transcripts peaked at 20 DAF but the proteins were distinctly up-regulated after 30 DAF. Stil also showed a slight difference in fluctuations at the protein and mRNA levels, since transcript abundance gradually rose to a peak at 20 DAF and the protein was constitutively expressed from 10 to 40 DAF.

In a comparison of transcriptome and proteome study during Arabidopsis seeds filling, Hajduch et al. (2010) reported that the observed correlation was only $56 \%$. Galland et al. (2012) also pointed out a poor correlation between RNA and protein abundance during seed germination of Arabidopsis. Thus, to assess changes in expression of stress-related genes in developing rice seeds and to thereby infer their physiological function by the accumulation patterns of the corresponding proteins, proteomic analysis, which directly detects the proteins, is more appropriate than analysis of transcript abundance.

This poor correlation between protein levels and mRNA abundance of stress-related proteins during seed desiccation may be caused by post-transcriptional, 
translational, and/or post-translational regulation of gene expression. Even when mRNA for stress-related proteins accumulates in cells of seeds, the protein levels do not increase unless translation occurs. On the other hand, the levels of highly stable proteins do not decrease even when their mRNA is degraded. RNA-binding proteins (RBPs) govern many aspects of RNA stability and decay, as well as induction of translation by recognizing and binding to specific sequences in mRNAs at the post-transcriptional and translational levels (Lorković 2009). In developing rice seeds, 257 RBPs have been experimentally identified to date (Morris et al. 2011). In addition, Sano et al. (2012) have implicated RBPs as being involved in the selective machinery of translation in rice embryos. In mammalian cells, Schwanhäusser et al. (2011) demonstrated that proteins are, on average, five times more stable (median half-life of $46 \mathrm{~h}$ ) than mRNAs ( $9 \mathrm{~h}$ ) and span a wider dynamic range, from 0.5 to $200 \mathrm{~h}$. These types of machinery may also modulate expression of stressrelated proteins involved in rice seed development.

\section{Isoforms of stress-related proteins in rice seeds}

In our 2-DE analysis, isoforms of stress-related proteins could be detected during rice seed development. A $70 \mathrm{kDa}$ HSP (spot 3) and a putative aldose reductase (spot 7) appeared as two protein spots, and a putative embryo-specific protein (spot 10), one of the LEA proteins, as three spots. In cultured soybean cells, a type of $70 \mathrm{kDa}$ HSP (binding immunoglobulin protein) localized to the endoplasmic reticulum undergoes phosphorylation under water stress (Cascardo et al. 2000). In addition, phosphorylated LEA protein is present in mature dry seeds of Arabidopsis (Irar et al. 2006). Moreover, Job et al. (2005) reported that aldose reductase and LEA protein are some of the specific proteins undergoing carbonylation during seed germination in Arabidopsis. These reports suggest that these isoforms we detected may correspond to forms modified post-translationally.

Furthermore, one isoform of a putative aldose reductase (spot $7 b$ ) and one of a LEA protein (spot 10c) were not detected until 20 DAF but were up-regulated at $30 \mathrm{DAF}$, whereas other isoforms of these proteins (spots $7 \mathrm{a}$ and $10 \mathrm{a}$ and $10 \mathrm{~b}$ ) were evident by 20 DAF (Figure 5). This indicates that the post-translational modification of the forms of these proteins up-regulated at 30 DAF may be specifically implicated in desiccation tolerance of rice seeds at the desiccation phase. To obtain an accurate understanding of the physiological function of such protein modifications on acquisition of desiccation tolerance, further studies on isoforms and post-translational control of these stress-related proteins will be required.

\section{References}

Anderson L, Seilhamer J (1997) A comparison of selected mRNA and protein abundances in human liver. Electrophoresis 18: 533-537

Angelovici R, Galili G, Fernie AR, Fait A (2010) Seed desiccation: a bridge between maturation and germination. Trends Plant Sci 15: 211-218

Bailly C, El-Maarouf-Bouteau H, Corbineau F (2008) From intracellular signaling networks to cell death: the dual role of reactive oxygen species in seed physiology. C R Biol 331: 806-814

Cascardo JC, Almeida RS, Buzeli RA, Carolino SM, Otoni WC, Fontes EP (2000) The phosphorylation state and expression of soybean $\mathrm{BiP}$ isoforms are differentially regulated following abiotic stresses. J Biol Chem 275: 14494-14500

Chevalier F (2010) Highlights on the capacities of "Gel-based" proteomics. Proteome Sci 8: 23

Cho EK, Hong CB (2006) Over-expression of tobacco NtHSP70-1 contributes to drought-stress tolerance in plants. Plant Cell Rep 25: $349-358$

Cuming AC (1999) LEA proteins. In: Shewry PR, Casey R (eds.) In Seed Proteins. Kluwer Academic Publishers, Dordrecht, pp 753-780

Farrant JM, Moore JP (2011) Programming desiccation-tolerance: from plants to seeds to resurrection plants. Curr Opin Plant Biol 14: $340-345$

Flom G, Weekes J, Williams JJ, Johnson JL (2006) Effect of mutation of the tetratricopeptide repeat and asparatate-proline 2 domains of Stil on Hsp90 signaling and interaction in Saccharomyces cerevisiae. Genetics 172: 41-51

Galland M, Job D, Rajjou L (2012) The seed proteome web portal. Front Plant Sci 3: 98

Gygi SP, Rochon Y, Franza BR, Aebersold R (1999) Correlation between protein and mRNA abundance in yeast. Mol Cell Biol 19: $1720-1730$

Hajduch M, Hearne LB, Miernyk JA, Casteel JE, Joshi T, Agrawal GK, Song Z, Zhou M, Xu D, Thelen JJ (2010) Systems analysis of seed filling in Arabidopsis: using general linear modeling to assess concordance of transcript and protein expression. Plant Physiol 152: 2078-2087

Haslekås C, Viken MK, Grini PE, Nygaard V, Nordgard SH, Meza TJ, Aalen RB (2003) Seed 1-cysteine peroxiredoxin antioxidants are not involved in dormancy, but contribute to inhibition of germination during stress. Plant Physiol 133: 1148-1157

Hoekstra FA, Golovina EA, Buitink J (2001) Mechanisms of plant desiccation tolerance. Trends Plant Sci 6: 431-438

Irar S, Oliveira E, Pagès M, Goday A (2006) Towards the identification of late-embryogenic-abundant phosphoproteome in Arabidopsis by 2-DE and MS. Proteomics 6 (Suppl 1): S175-S185

Ishimaru T, Matsuda T, Ohsugi R, Yamagishi T (2003) Morphological development of rice caryopses located at the different positions in a panicle from early to middle stage of grain filling. Funct Plant Biol 30: 1139-1149

Jensen AB, Busk PK, Figueras M, Albà MM, Peracchia G, Messeguer R, Goday A, Pagès M (1996) Drought signal transduction in plants. Plant Growth Regul 20: 105-110

Job C, Rajjou L, Lovigny Y, Belghazi M, Job D (2005) Patterns of protein oxidation in Arabidopsis seeds and during germination. Plant Physiol 138: 790-802

Kalemba EM, Pukacka S (2007) Possible roles of LEA proteins and sHSPs in seed protection: a short review. Biol Lett 44: 3-16 
Karuna Sree B, Rajendrakumar CS, Reddy AR (2000) Aldose reductase in rice (Oryza sativa L.): stress response and developmental specificity. Plant Sci 160: 149-157

Lee J, Koh HJ (2011) A label-free quantitative shotgun proteomics analysis of rice grain development. Proteome Sci 9: 61

Li QF, Sun S, Yuan DY, Yu HX, Gu MH, Liu QQ (2010) Validation of candidate reference genes for the accurate normalization of real-time quantitative RT-PCR data in rice during seed development. Plant Mol Biol Rep 28: 49-57

Lorković ZJ (2009) Role of plant RNA-binding proteins in development, stress response and genome organization. Trends Plant Sci 14: 229-236

Mittler R (2002) Oxidative stress, antioxidants and stress tolerance. Trends Plant Sci 7: 405-410

Mittler R, Vanderauwera S, Gollery M, Van Breusegem F (2004) Reactive oxygen gene network of plants. Trends Plant Sci 9: 490-498

Morey JS, Ryan JC, Van Dolah FM (2006) Microarray validation: factors influencing correlation between oligonucleotide microarrays and real-time PCR. Biol Proced Online 8: 175-193

Morris RT, Doroshenk KA, Crofts AJ, Lewis N, Okita TW, Wyrick JJ (2011) RiceRBP: a database of experimentally identified RNAbinding proteins in Oryza sativa L. Plant Sci 180: 204-211

Mustafiz A, Sahoo KK, Singla-Pareek SL, Sopory SK (2010) Metabolic engineering of glyoxalase pathway for enhancing stress tolerance in plants. Methods Mol Biol 639: 95-118

Mustafiz A, Singh AK, Pareek A, Sopory SK, Singla-Pareek SL (2011) Genome-wide analysis of rice and Arabidopsis identifies two glyoxalase genes that are highly expressed in abiotic stresses. Funct Integr Genomics 11: 293-305

Nambara E, Marion-Poll A (2003) ABA action and interactions in seeds. Trends Plant Sci 8: 213-217

Potts M (1994) Desiccation tolerance of prokaryotes. Microbiol Rev 58: 755-805

Sales K, Brandt W, Rumbak E, Lindsey G (2000) The LEA-like protein HSP 12 in Saccharomyces cerevisiae has a plasma membrane location and protects membranes against desiccation and ethanol-induced stress. Biochim Biophys Acta 1463: 267-278

Sallon S, Solowey E, Cohen Y, Korchinsky R, Egli M, Woodhatch I, Simchoni O, Kislev M (2008) Germination, genetics, and growth of an ancient date seed. Science 320: 1464

Sano N, Permana H, Kumada R, Shinozaki Y, Tanabata T, Yamada T, Hirasawa T, Kanekatsu M (2012) Proteomic analysis of embryonic proteins synthesized from long-lived mRNAs during germination of rice seeds. Plant Cell Physiol 53: 687-698

Sarkar NK, Kim YK, Grover A (2009) Rice sHsp genes: genomic organization and expression profiling under stress and development. BMC Genomics 10: 393

Schwanhäusser B, Busse D, Li N, Dittmar G, Schuchhardt J, Wolf J, Chen W, Selbach M (2011) Global quantification of mammalian gene expression control. Nature 473: 337-342

Shimizu T, Kanamori Y, Furuki T, Kikawada T, Okuda T, Takahashi T, Mihara H, Sakurai M (2010) Desiccationinduced structuralization and glass formation of group 3 late embryogenesis abundant protein model peptides. Biochemistry 49: 1093-1104

Still DW, Kovach DA, Bradford KJ (1994) Development of Desiccation Tolerance during Embryogenesis in Rice (Oryza sativa) and Wild Rice (Zizania palustris) (Dehydrin Expression, Abscisic Acid Content, and Sucrose Accumulation). Plant Physiol 104: 431-438

Trent JD (1996) A review of acquired thermotolerance, heat shock proteins, and molecular chaperones in archaea. FEMS Microbiol Rev 18: 249-258

Viitanen PV, Schmidt M, Buchner J, Suzuki T, Vierling E, Dickson R, Lorimer GH, Gatenby A, Soll J (1995) Functional characterization of the higher plant chloroplast chaperonins. $J$ Biol Chem 270: 18158-18164

Wehmeyer N, Hernandez LD, Finkelstein RR, Vierling E (1996) Synthesis of small heat-shock proteins is part of the developmental program of late seed maturation. Plant Physiol 112: 747-757

Wessel D, Flügge UI (1984) A method for the quantitative recovery of protein in dilute solution in the presence of detergents and lipids. Anal Biochem 138: 141-143

Xu H, Zhang W, Gao Y, Zhao Y, Guo L, Wang J (2012) Proteomic analysis of embryo development in rice (Oryza sativa). Planta 235: 687-701

Xu SB, Li T, Deng ZY, Chong K, Xue Y, Wang T (2008) Dynamic proteomic analysis reveals a switch between central carbon metabolism and alcoholic fermentation in rice filling grains. Plant Physiol 148: 908-925

Yan JX, Sanchez JC, Tonella L, Williams KL, Hochstrasser DF (1999) Studies of quantitative analysis of protein expression in Saccharomyces cerevisiae. Electrophoresis 20: 738-742

Zou J, Liu A, Chen X, Zhou X, Gao G, Wang W, Zhang X (2009) Expression analysis of nine rice heat shock protein genes under abiotic stresses and ABA treatment. J Plant Physiol 166: 851-861 
Supplementary Table 1. Sequences of primer sets for real-time RT-PCR analysis.

\begin{tabular}{|c|c|c|c|c|}
\hline \multirow{2}{*}{ Spot No. ${ }^{a}$} & \multirow{2}{*}{ Gene name } & \multicolumn{2}{|c|}{ Primer sequence $\left(5^{\prime}\right.$ to $\left.3^{\prime}\right)$} & \multirow{2}{*}{$\begin{array}{l}\text { Product size } \\
\quad \text { (bp) }\end{array}$} \\
\hline & & Forward & Reverse & \\
\hline 1 & $18.1 \mathrm{kDa}$ heat shock protein & CTGTCGTGAAGGAGCAAATAAAATC & GCACTGGAACAACACACTGACC & 114 \\
\hline 2 & $16.9 \mathrm{kDa}$ heat shock protein & GTATGGTCTGCTGCTGGTGTGT & TCCTCAACGAGCAAGAACTAAGAAG & 120 \\
\hline $3 a, 3 b$ & $70 \mathrm{kDa}$ heat shock protein & ATCTGTGGTGGATGGCTGTG & GGCAAAACCCTACGCTATCAA & 139 \\
\hline 4 & glyoxalase I & AGGAGGCAAAGCACAAACC & GATTTACAGCCAAACCCAGACA & 136 \\
\hline 5 & $\begin{array}{l}\text { putative stress-induced } \\
\text { protein stil }\end{array}$ & TTCCATGCTCAGTCTTTGTGG & GGCTCTATTTTCATTCGGTAGGG & 192 \\
\hline 6 & peroxiredoxin & GGCGTGATGACTATGCGAGA & TACAGGGGCGAACATACGG & 148 \\
\hline $7 a, 7 b$ & putative aldose reductase & CATCTGAGGTCTGGGATAACGA & CAGTGCTTGGAGAACATCACATAAC & 117 \\
\hline 8 & $\begin{array}{l}\text { putative embryonic } \\
\text { abundant protein, } \\
\text { group } 3\end{array}$ & CAAGAAGCAGAGAGCGAAGC & TGCATGGACGCCATTGAT & 101 \\
\hline 9 & $\begin{array}{l}\text { late embryogenesis } \\
\text { abundant protein } 1\end{array}$ & CGCGGTGGACGACTAATAAAA & AAGGAACATACACGGTAGTGGAAAC & 113 \\
\hline $\begin{array}{l}10 \mathrm{a}, 10 \mathrm{~b} \\
10 \mathrm{c}\end{array}$ & $\begin{array}{l}\text { putative embryo-specific } \\
\text { protein }\end{array}$ & ATGCAACAGCATACAGAAAACG & ACACCGATTAGCCCATGTCAA & 100 \\
\hline 11 & putative $20 \mathrm{kDa}$ chaperonin & CAACGCTCTTGCGAAATAGGA & GCAGTGACATCAAGTAGGAATAGCA & 133 \\
\hline 12 & $\begin{array}{l}\text { putative chaperonin } 21 \\
\text { precursor }\end{array}$ & GACGGTAGCAGGTGGTAATGG & ACAGTGGAATGTTGATCCCGTAG & 124 \\
\hline $\begin{array}{l}\text { internal } \\
\text { standard }\end{array}$ & $\operatorname{actin} 1$ & CCGTCCTCCTGCTTGTTTCT & TGGTACCCTCATCAGGCATC & 197 \\
\hline
\end{tabular}

${ }^{\mathrm{a}}$ Consistent with the spot numbers in Figure 2. 
Supplementary Table 2. Identification of proteins in mature seeds of rice.

\begin{tabular}{|c|c|c|c|c|c|c|c|c|c|}
\hline \multirow{2}{*}{ Spot No. ${ }^{a}$} & \multirow{2}{*}{ Protein name } & \multicolumn{2}{|c|}{$\mathrm{p} I^{\mathrm{b}}$} & \multicolumn{2}{|c|}{$\mathrm{Mr}(\mathrm{kDa})^{\mathrm{c}}$} & \multirow{2}{*}{ Score $^{\mathrm{d}}$} & \multirow{2}{*}{$\begin{array}{c}\text { Cov. }^{\mathrm{e}} \\
(\%)\end{array}$} & \multirow{2}{*}{$\begin{array}{l}\text { Pept. } \\
\text { Match }\end{array}$} & \multirow{2}{*}{ Accession No. ${ }^{g}$} \\
\hline & & Exp. & Theo. & Exp. & Theo. & & & & \\
\hline 1 & $18.1 \mathrm{kDa}$ heat shock protein & 5.9 & 5.8 & 19.6 & 17.9 & 75 & 27 & 3 & LOC_Os03g15960 \\
\hline 2 & $16.9 \mathrm{kDa}$ heat shock protein & 6.3 & 6.2 & 18.2 & 16.9 & 85 & 42 & 5 & LOC_Os01g04370 \\
\hline $3 a$ & $70 \mathrm{kDa}$ heat shock protein & 4.9 & 5.1 & 81.5 & 74.3 & 84 & 13 & 6 & LOC_Os12g14070 \\
\hline $3 b$ & & 4.8 & & 81.0 & & 85 & 13 & 7 & \\
\hline 4 & glyoxalase I & 5.6 & 5.5 & 39.5 & 32.9 & 72 & 38 & 5 & LOC_Os08g09250 \\
\hline 5 & $\begin{array}{l}\text { putative stress-induced } \\
\text { protein stil }\end{array}$ & 6.4 & 6.0 & 59.8 & 69.4 & 102 & 16 & 7 & LOC_Os02g43020 \\
\hline 6 & peroxiredoxin & 6.6 & 6.0 & 30.2 & 24.0 & 152 & 57 & 5 & LOC_Os07g44430 \\
\hline $7 \mathrm{a}$ & putative aldose reductase & 6.7 & 6.3 & 39.4 & 35.6 & 132 & 42 & 7 & LOC_Os05g39680 \\
\hline $7 \mathrm{~b}$ & & 6.3 & & 33.1 & & 72 & 30 & 4 & \\
\hline 8 & $\begin{array}{l}\text { putative embryonic abundant } \\
\text { protein, group } 3\end{array}$ & 6.3 & 6.1 & 34.2 & 24.5 & 79 & 31 & 4 & LOC_Os01g16920 \\
\hline 9 & $\begin{array}{l}\text { late embryogenesis abundant } \\
\text { protein } 1\end{array}$ & 6.6 & 6.4 & 43.8 & 36.8 & 89 & 25 & 5 & LOC_Os03g20680 \\
\hline $10 \mathrm{a}$ & putative embryo-specific & 7.3 & 8.3 & 44.8 & 41.8 & 71 & 26 & 9 & LOC_Os03g07180 \\
\hline $10 \mathrm{~b}$ & protein & 7.4 & & 44.8 & & 87 & 26 & 9 & \\
\hline $10 \mathrm{c}$ & & 7.5 & & 44.0 & & 70 & 25 & 9 & \\
\hline 11 & putative $20 \mathrm{kDa}$ chaperonin & 5.1 & 6.0 & 35.2 & 25.5 & 87 & 31 & 4 & LOC_Os09g26730 \\
\hline 12 & $\begin{array}{l}\text { putative chaperonin } 21 \\
\text { precursor }\end{array}$ & 5.7 & 7.7 & 34.2 & 26.3 & 102 & 38 & 6 & LOC_Os06g09679 \\
\hline $13 \mathrm{a}$ & protein disulfide isomerase & 4.8 & 5.1 & 57.0 & 57.4 & 130 & 24 & 7 & LOC_Os11g09280 \\
\hline $13 b$ & & 4.8 & & 57.0 & & 140 & 26 & 8 & \\
\hline 14 & unnamed protein product & 4.7 & 4.8 & 17.3 & 21.4 & 134 & 50 & 6 & LOC_Os04g39150 \\
\hline 15 & $\begin{array}{l}\text { putative aspartate } \\
\text { transaminase }\end{array}$ & 8.1 & 6.7 & 48.5 & 43.0 & 101 & 25 & 8 & LOC_Os02g14110 \\
\hline 16 & $\begin{array}{l}\text { putative phosphoglycerate } \\
\text { mutase }\end{array}$ & 5.4 & 5.5 & 60.7 & 64.6 & 124 & 24 & 7 & LOC_Os01g60190 \\
\hline 17 & enolase & 5.3 & 5.6 & 48.3 & 48.4 & 74 & 18 & 5 & LOC_Os03g14450 \\
\hline 18 & enolase & 5.5 & 5.6 & 47.9 & 47.9 & 105 & 20 & 7 & LOC_Os10g08550 \\
\hline 19 & $\begin{array}{l}\text { putative ATP synthase beta } \\
\text { subunit }\end{array}$ & 5.3 & 5.5 & 45.3 & 47.4 & 108 & 28 & 7 & LOC_Os01g49190 \\
\hline 20 & $\begin{array}{l}\text { UDP-glucose } \\
\text { pyrophosphorylase }\end{array}$ & 5.4 & 5.7 & 51.7 & 47.4 & 132 & 26 & 9 & LOC_Os09g38030 \\
\hline 21 & alanine aminotransferase & 6.2 & 6.5 & 53.1 & 47.5 & 171 & 32 & 8 & LOC_Os10g25130 \\
\hline 22 & $\begin{array}{l}\text { cytoplasmic malate } \\
\text { dehydrogenase }\end{array}$ & 5.8 & 6.1 & 34.3 & 42.3 & 85 & 34 & 5 & LOC_Os10g33800 \\
\hline 23 & $\begin{array}{l}\text { receptor for activated } \mathrm{C} \\
\text { kinase } 1 \mathrm{~A}\end{array}$ & 6.0 & 6.3 & 36.2 & 41.4 & 88 & 34 & 5 & LOC_Os01g49290 \\
\hline 24 & $\begin{array}{l}\text { putative triosephosphate } \\
\text { isomerase }\end{array}$ & 5.4 & 5.3 & 27.3 & 34.2 & 132 & 40 & 5 & LOC_Os01g05490 \\
\hline $25 \mathrm{a}$ & globulin-like protein & 6.8 & 6.8 & 57.3 & 52.4 & 131 & 30 & 10 & LOC_Os03g57960 \\
\hline $25 b$ & & 9.6 & & 22.3 & & 78 & 18 & 7 & \\
\hline $25 c$ & & 6.9 & & 57.3 & & 157 & 33 & 9 & \\
\hline 26 & $\begin{array}{l}\text { putative sorbitol } \\
\text { dehydrogenase }\end{array}$ & 6.0 & 6.3 & 40.0 & 43.8 & 111 & 30 & 8 & LOC_Os08g43190 \\
\hline 27 & $\begin{array}{l}\text { NAD-dependent formate } \\
\text { dehydrogenase }\end{array}$ & 6.7 & 6.8 & 41.5 & 44.8 & 149 & 32 & 6 & LOC_Os06g29180 \\
\hline 28 & $\begin{array}{l}\text { glucose and ribitol } \\
\text { dehydrogenase homolog }\end{array}$ & 5.8 & 5.9 & 32.5 & 41.0 & 83 & 30 & 5 & LOC_Os05g04870 \\
\hline 29 & putative $\mathrm{r} 40 \mathrm{c} 1$ protein & 6.2 & 6.3 & 38.8 & 41.8 & 198 & 48 & 8 & LOC_Os03g21040 \\
\hline 30 & $\begin{array}{l}\text { glyceraldehyde-3-phosphate } \\
\text { dehydrogenase }\end{array}$ & 6.3 & 6.8 & 36.9 & 43.3 & 84 & 28 & 6 & LOC_Os04g40950 \\
\hline 31 & $\begin{array}{l}\text { glyceraldehyde-3-phosphate } \\
\text { dehydrogenase }\end{array}$ & 6.6 & 7.1 & 36.7 & 44.0 & 119 & 36 & 6 & LOC_Os08g03290 \\
\hline 32 & aldolase C-1 & 8.4 & 8.1 & 38.8 & 44.0 & 73 & 32 & 6 & LOC_Os01g67860 \\
\hline 33 & putative glucanase & 5.3 & 5.5 & 34.2 & 39.5 & 101 & 34 & 3 & LOC_Os05g31140 \\
\hline $34 \mathrm{a}$ & hypothetical protein & 5.6 & 5.8 & 35.4 & 40.0 & 131 & 37 & 8 & LOC_Os10g32680 \\
\hline $34 \mathrm{~b}$ & OsJ_31810 & 5.6 & & 35.4 & & 74 & 15 & 6 & \\
\hline 35 & putative Bowman Birk trypsin & 6.6 & 6.6 & 15.4 & 18.2 & 90 & 34 & 5 & LOC_Os01g03360 \\
\hline
\end{tabular}


Supplementary Table 2. Identification of proteins in mature seeds of rice.

\begin{tabular}{|c|c|c|c|c|c|c|c|c|c|}
\hline \multirow{2}{*}{ Spot No. ${ }^{a}$} & \multirow{2}{*}{ Protein name } & \multicolumn{2}{|c|}{$\mathrm{p} I^{\mathrm{b}}$} & \multicolumn{2}{|c|}{$\operatorname{Mr}(\mathrm{kDa})^{\mathrm{c}}$} & \multirow{2}{*}{ Score ${ }^{\mathrm{d}}$} & \multirow{2}{*}{$\begin{array}{c}\text { Cove }^{\mathrm{e}} \\
(\%)\end{array}$} & \multirow{2}{*}{$\begin{array}{l}\text { Pept. } \\
\text { Match }\end{array}$} & \multirow{2}{*}{ Accession No. ${ }^{g}$} \\
\hline & & Exp. & Theo. & Exp. & Theo. & & & & \\
\hline 36 & $\alpha$-amylase/subtilisin inhibitor & 8.7 & 8.6 & 21.7 & 21.9 & 109 & 41 & 4 & LOC_Os04g44470 \\
\hline 37 & $\begin{array}{l}\text { peptidylprolyl isomerase } \\
\text { Cyp2 }\end{array}$ & 8.6 & 8.3 & 18.6 & 19.0 & 102 & 31 & 4 & LOC_Os02g02890 \\
\hline 38 & $\begin{array}{l}\text { hypothetical protein } \\
\text { OsJ_10338 }\end{array}$ & 5.5 & 5.5 & 15.0 & 14.5 & 134 & 71 & 2 & LOC_Os03g16940 \\
\hline 39 & $\begin{array}{l}\text { nucleoside diphosphate } \\
\text { kinase I }\end{array}$ & 6.3 & 6.5 & 16.9 & 15.6 & 102 & 42 & 4 & LOC_Os07g30970 \\
\hline 40 & putative allergenic protein & 8.7 & 8.0 & 17.8 & 41.5 & 66 & 36 & 4 & LOC_Os07g11330 \\
\hline 41 & putative legumin & 5.8 & 6.1 & 38.5 & 41.8 & 75 & 27 & 5 & LOC_Os05g02520 \\
\hline $42 \mathrm{a}$ & glutelin & 6.6 & 6.9 & 36.0 & 40.5 & 127 & 26 & 4 & LOC_Os02g16820 \\
\hline $42 \mathrm{~b}$ & & & 7.1 & & 39.0 & 130 & 21 & 4 & \\
\hline $43 a$ & $26 \mathrm{kDa}$ globulin & 6.3 & 7.5 & 26.5 & 21.5 & 80 & 27 & 3 & LOC_Os05g41970 \\
\hline $43 b$ & & 5.5 & & & & 88 & 27 & 3 & \\
\hline $44 a$ & hypothetical protein & 5.4 & 9.1 & 38.5 & 54.5 & 152 & 31 & 7 & LOC_Os03g46100 \\
\hline $44 \mathrm{~b}$ & OsJ_13801 & 5.6 & & 38.0 & & 121 & 28 & 6 & \\
\hline $44 \mathrm{c}$ & & 5.7 & & 38.0 & & 139 & 33 & 6 & \\
\hline $44 \mathrm{~d}$ & & 7.3 & & 23.2 & & 80 & 19 & 5 & \\
\hline
\end{tabular}

${ }^{\mathrm{a}}$ Consistent with the spot numbers in Figure 2. ${ }^{\mathrm{b}} \mathrm{p} I$ Exp. is experimental isoelectric point, Theo. is theoretical isoelectric point. ${ }^{\mathrm{c}} \mathrm{Mr}(\mathrm{kDa})$ Exp. is experimental molecular size, Theo. is theoretical molecular size. ${ }^{\mathrm{d}}$ The protein score is $-10 * \log (\mathrm{P})$, where $\mathrm{P}$ is the probability that the observed match is a random event. Protein scores greater than 64 are significant $(p<0.05) .{ }^{e}$ Sequence coverage $(\%) .{ }^{\mathrm{f}}$ Number of matched peptides. ${ }^{\mathrm{g}}$ Accession number of the matched protein in the MSU Rice Genome Annotation (http://rice.plantbiology.msu.edu/). 
Supplementary Table 1. Sequences of primer sets for real-time RT-PCR analysis.

\begin{tabular}{|c|c|c|c|c|}
\hline \multirow{2}{*}{ Spot No. ${ }^{a}$} & \multirow{2}{*}{ Gene name } & \multicolumn{2}{|c|}{ Primer sequence $\left(5^{\prime}\right.$ to $\left.3^{\prime}\right)$} & \multirow{2}{*}{$\begin{array}{l}\text { Product size } \\
\quad \text { (bp) }\end{array}$} \\
\hline & & Forward & Reverse & \\
\hline 1 & $18.1 \mathrm{kDa}$ heat shock protein & CTGTCGTGAAGGAGCAAATAAAATC & GCACTGGAACAACACACTGACC & 114 \\
\hline 2 & $16.9 \mathrm{kDa}$ heat shock protein & GTATGGTCTGCTGCTGGTGTGT & TCCTCAACGAGCAAGAACTAAGAAG & 120 \\
\hline $3 a, 3 b$ & $70 \mathrm{kDa}$ heat shock protein & ATCTGTGGTGGATGGCTGTG & GGCAAAACCCTACGCTATCAA & 139 \\
\hline 4 & glyoxalase I & AGGAGGCAAAGCACAAACC & GATTTACAGCCAAACCCAGACA & 136 \\
\hline 5 & $\begin{array}{l}\text { putative stress-induced } \\
\text { protein stil }\end{array}$ & TTCCATGCTCAGTCTTTGTGG & GGCTCTATTTTCATTCGGTAGGG & 192 \\
\hline 6 & peroxiredoxin & GGCGTGATGACTATGCGAGA & TACAGGGGCGAACATACGG & 148 \\
\hline $7 a, 7 b$ & putative aldose reductase & CATCTGAGGTCTGGGATAACGA & CAGTGCTTGGAGAACATCACATAAC & 117 \\
\hline 8 & $\begin{array}{l}\text { putative embryonic } \\
\text { abundant protein, } \\
\text { group } 3\end{array}$ & CAAGAAGCAGAGAGCGAAGC & TGCATGGACGCCATTGAT & 101 \\
\hline 9 & $\begin{array}{l}\text { late embryogenesis } \\
\text { abundant protein } 1\end{array}$ & CGCGGTGGACGACTAATAAAA & AAGGAACATACACGGTAGTGGAAAC & 113 \\
\hline $\begin{array}{l}10 \mathrm{a}, 10 \mathrm{~b} \\
10 \mathrm{c}\end{array}$ & $\begin{array}{l}\text { putative embryo-specific } \\
\text { protein }\end{array}$ & ATGCAACAGCATACAGAAAACG & ACACCGATTAGCCCATGTCAA & 100 \\
\hline 11 & putative $20 \mathrm{kDa}$ chaperonin & CAACGCTCTTGCGAAATAGGA & GCAGTGACATCAAGTAGGAATAGCA & 133 \\
\hline 12 & $\begin{array}{l}\text { putative chaperonin } 21 \\
\text { precursor }\end{array}$ & GACGGTAGCAGGTGGTAATGG & ACAGTGGAATGTTGATCCCGTAG & 124 \\
\hline $\begin{array}{l}\text { internal } \\
\text { standard }\end{array}$ & $\operatorname{actin} 1$ & CCGTCCTCCTGCTTGTTTCT & TGGTACCCTCATCAGGCATC & 197 \\
\hline
\end{tabular}

${ }^{\mathrm{a}}$ Consistent with the spot numbers in Figure 2. 
Supplementary Table 2. Identification of proteins in mature seeds of rice.

\begin{tabular}{|c|c|c|c|c|c|c|c|c|c|}
\hline \multirow{2}{*}{ Spot No. ${ }^{a}$} & \multirow{2}{*}{ Protein name } & \multicolumn{2}{|c|}{$\mathrm{p} I^{\mathrm{b}}$} & \multicolumn{2}{|c|}{$\mathrm{Mr}(\mathrm{kDa})^{\mathrm{c}}$} & \multirow{2}{*}{ Score $^{\mathrm{d}}$} & \multirow{2}{*}{$\begin{array}{c}\text { Cov. }^{\mathrm{e}} \\
(\%)\end{array}$} & \multirow{2}{*}{$\begin{array}{l}\text { Pept. } \\
\text { Match }\end{array}$} & \multirow{2}{*}{ Accession No. ${ }^{g}$} \\
\hline & & Exp. & Theo. & Exp. & Theo. & & & & \\
\hline 1 & $18.1 \mathrm{kDa}$ heat shock protein & 5.9 & 5.8 & 19.6 & 17.9 & 75 & 27 & 3 & LOC_Os03g15960 \\
\hline 2 & $16.9 \mathrm{kDa}$ heat shock protein & 6.3 & 6.2 & 18.2 & 16.9 & 85 & 42 & 5 & LOC_Os01g04370 \\
\hline $3 a$ & $70 \mathrm{kDa}$ heat shock protein & 4.9 & 5.1 & 81.5 & 74.3 & 84 & 13 & 6 & LOC_Os12g14070 \\
\hline $3 b$ & & 4.8 & & 81.0 & & 85 & 13 & 7 & \\
\hline 4 & glyoxalase I & 5.6 & 5.5 & 39.5 & 32.9 & 72 & 38 & 5 & LOC_Os08g09250 \\
\hline 5 & $\begin{array}{l}\text { putative stress-induced } \\
\text { protein stil }\end{array}$ & 6.4 & 6.0 & 59.8 & 69.4 & 102 & 16 & 7 & LOC_Os02g43020 \\
\hline 6 & peroxiredoxin & 6.6 & 6.0 & 30.2 & 24.0 & 152 & 57 & 5 & LOC_Os07g44430 \\
\hline $7 \mathrm{a}$ & putative aldose reductase & 6.7 & 6.3 & 39.4 & 35.6 & 132 & 42 & 7 & LOC_Os05g39680 \\
\hline $7 \mathrm{~b}$ & & 6.3 & & 33.1 & & 72 & 30 & 4 & \\
\hline 8 & $\begin{array}{l}\text { putative embryonic abundant } \\
\text { protein, group } 3\end{array}$ & 6.3 & 6.1 & 34.2 & 24.5 & 79 & 31 & 4 & LOC_Os01g16920 \\
\hline 9 & $\begin{array}{l}\text { late embryogenesis abundant } \\
\text { protein } 1\end{array}$ & 6.6 & 6.4 & 43.8 & 36.8 & 89 & 25 & 5 & LOC_Os03g20680 \\
\hline $10 \mathrm{a}$ & putative embryo-specific & 7.3 & 8.3 & 44.8 & 41.8 & 71 & 26 & 9 & LOC_Os03g07180 \\
\hline $10 \mathrm{~b}$ & protein & 7.4 & & 44.8 & & 87 & 26 & 9 & \\
\hline $10 \mathrm{c}$ & & 7.5 & & 44.0 & & 70 & 25 & 9 & \\
\hline 11 & putative $20 \mathrm{kDa}$ chaperonin & 5.1 & 6.0 & 35.2 & 25.5 & 87 & 31 & 4 & LOC_Os09g26730 \\
\hline 12 & $\begin{array}{l}\text { putative chaperonin } 21 \\
\text { precursor }\end{array}$ & 5.7 & 7.7 & 34.2 & 26.3 & 102 & 38 & 6 & LOC_Os06g09679 \\
\hline $13 \mathrm{a}$ & protein disulfide isomerase & 4.8 & 5.1 & 57.0 & 57.4 & 130 & 24 & 7 & LOC_Os11g09280 \\
\hline $13 b$ & & 4.8 & & 57.0 & & 140 & 26 & 8 & \\
\hline 14 & unnamed protein product & 4.7 & 4.8 & 17.3 & 21.4 & 134 & 50 & 6 & LOC_Os04g39150 \\
\hline 15 & $\begin{array}{l}\text { putative aspartate } \\
\text { transaminase }\end{array}$ & 8.1 & 6.7 & 48.5 & 43.0 & 101 & 25 & 8 & LOC_Os02g14110 \\
\hline 16 & $\begin{array}{l}\text { putative phosphoglycerate } \\
\text { mutase }\end{array}$ & 5.4 & 5.5 & 60.7 & 64.6 & 124 & 24 & 7 & LOC_Os01g60190 \\
\hline 17 & enolase & 5.3 & 5.6 & 48.3 & 48.4 & 74 & 18 & 5 & LOC_Os03g14450 \\
\hline 18 & enolase & 5.5 & 5.6 & 47.9 & 47.9 & 105 & 20 & 7 & LOC_Os10g08550 \\
\hline 19 & $\begin{array}{l}\text { putative ATP synthase beta } \\
\text { subunit }\end{array}$ & 5.3 & 5.5 & 45.3 & 47.4 & 108 & 28 & 7 & LOC_Os01g49190 \\
\hline 20 & $\begin{array}{l}\text { UDP-glucose } \\
\text { pyrophosphorylase }\end{array}$ & 5.4 & 5.7 & 51.7 & 47.4 & 132 & 26 & 9 & LOC_Os09g38030 \\
\hline 21 & alanine aminotransferase & 6.2 & 6.5 & 53.1 & 47.5 & 171 & 32 & 8 & LOC_Os10g25130 \\
\hline 22 & $\begin{array}{l}\text { cytoplasmic malate } \\
\text { dehydrogenase }\end{array}$ & 5.8 & 6.1 & 34.3 & 42.3 & 85 & 34 & 5 & LOC_Os10g33800 \\
\hline 23 & $\begin{array}{l}\text { receptor for activated } \mathrm{C} \\
\text { kinase } 1 \mathrm{~A}\end{array}$ & 6.0 & 6.3 & 36.2 & 41.4 & 88 & 34 & 5 & LOC_Os01g49290 \\
\hline 24 & $\begin{array}{l}\text { putative triosephosphate } \\
\text { isomerase }\end{array}$ & 5.4 & 5.3 & 27.3 & 34.2 & 132 & 40 & 5 & LOC_Os01g05490 \\
\hline $25 \mathrm{a}$ & globulin-like protein & 6.8 & 6.8 & 57.3 & 52.4 & 131 & 30 & 10 & LOC_Os03g57960 \\
\hline $25 b$ & & 9.6 & & 22.3 & & 78 & 18 & 7 & \\
\hline $25 c$ & & 6.9 & & 57.3 & & 157 & 33 & 9 & \\
\hline 26 & $\begin{array}{l}\text { putative sorbitol } \\
\text { dehydrogenase }\end{array}$ & 6.0 & 6.3 & 40.0 & 43.8 & 111 & 30 & 8 & LOC_Os08g43190 \\
\hline 27 & $\begin{array}{l}\text { NAD-dependent formate } \\
\text { dehydrogenase }\end{array}$ & 6.7 & 6.8 & 41.5 & 44.8 & 149 & 32 & 6 & LOC_Os06g29180 \\
\hline 28 & $\begin{array}{l}\text { glucose and ribitol } \\
\text { dehydrogenase homolog }\end{array}$ & 5.8 & 5.9 & 32.5 & 41.0 & 83 & 30 & 5 & LOC_Os05g04870 \\
\hline 29 & putative $\mathrm{r} 40 \mathrm{c} 1$ protein & 6.2 & 6.3 & 38.8 & 41.8 & 198 & 48 & 8 & LOC_Os03g21040 \\
\hline 30 & $\begin{array}{l}\text { glyceraldehyde-3-phosphate } \\
\text { dehydrogenase }\end{array}$ & 6.3 & 6.8 & 36.9 & 43.3 & 84 & 28 & 6 & LOC_Os04g40950 \\
\hline 31 & $\begin{array}{l}\text { glyceraldehyde-3-phosphate } \\
\text { dehydrogenase }\end{array}$ & 6.6 & 7.1 & 36.7 & 44.0 & 119 & 36 & 6 & LOC_Os08g03290 \\
\hline 32 & aldolase C-1 & 8.4 & 8.1 & 38.8 & 44.0 & 73 & 32 & 6 & LOC_Os01g67860 \\
\hline 33 & putative glucanase & 5.3 & 5.5 & 34.2 & 39.5 & 101 & 34 & 3 & LOC_Os05g31140 \\
\hline $34 \mathrm{a}$ & hypothetical protein & 5.6 & 5.8 & 35.4 & 40.0 & 131 & 37 & 8 & LOC_Os10g32680 \\
\hline $34 \mathrm{~b}$ & OsJ_31810 & 5.6 & & 35.4 & & 74 & 15 & 6 & \\
\hline 35 & putative Bowman Birk trypsin & 6.6 & 6.6 & 15.4 & 18.2 & 90 & 34 & 5 & LOC_Os01g03360 \\
\hline
\end{tabular}


Supplementary Table 2. Identification of proteins in mature seeds of rice.

\begin{tabular}{|c|c|c|c|c|c|c|c|c|c|}
\hline \multirow{2}{*}{ Spot No. ${ }^{a}$} & \multirow{2}{*}{ Protein name } & \multicolumn{2}{|c|}{$\mathrm{p} I^{\mathrm{b}}$} & \multicolumn{2}{|c|}{$\operatorname{Mr}(\mathrm{kDa})^{\mathrm{c}}$} & \multirow{2}{*}{ Score ${ }^{\mathrm{d}}$} & \multirow{2}{*}{$\begin{array}{c}\text { Cove }^{\mathrm{e}} \\
(\%)\end{array}$} & \multirow{2}{*}{$\begin{array}{l}\text { Pept. } \\
\text { Match }\end{array}$} & \multirow{2}{*}{ Accession No. ${ }^{g}$} \\
\hline & & Exp. & Theo. & Exp. & Theo. & & & & \\
\hline 36 & $\alpha$-amylase/subtilisin inhibitor & 8.7 & 8.6 & 21.7 & 21.9 & 109 & 41 & 4 & LOC_Os04g44470 \\
\hline 37 & $\begin{array}{l}\text { peptidylprolyl isomerase } \\
\text { Cyp2 }\end{array}$ & 8.6 & 8.3 & 18.6 & 19.0 & 102 & 31 & 4 & LOC_Os02g02890 \\
\hline 38 & $\begin{array}{l}\text { hypothetical protein } \\
\text { OsJ_10338 }\end{array}$ & 5.5 & 5.5 & 15.0 & 14.5 & 134 & 71 & 2 & LOC_Os03g16940 \\
\hline 39 & $\begin{array}{l}\text { nucleoside diphosphate } \\
\text { kinase I }\end{array}$ & 6.3 & 6.5 & 16.9 & 15.6 & 102 & 42 & 4 & LOC_Os07g30970 \\
\hline 40 & putative allergenic protein & 8.7 & 8.0 & 17.8 & 41.5 & 66 & 36 & 4 & LOC_Os07g11330 \\
\hline 41 & putative legumin & 5.8 & 6.1 & 38.5 & 41.8 & 75 & 27 & 5 & LOC_Os05g02520 \\
\hline $42 \mathrm{a}$ & glutelin & 6.6 & 6.9 & 36.0 & 40.5 & 127 & 26 & 4 & LOC_Os02g16820 \\
\hline $42 \mathrm{~b}$ & & & 7.1 & & 39.0 & 130 & 21 & 4 & \\
\hline $43 a$ & $26 \mathrm{kDa}$ globulin & 6.3 & 7.5 & 26.5 & 21.5 & 80 & 27 & 3 & LOC_Os05g41970 \\
\hline $43 b$ & & 5.5 & & & & 88 & 27 & 3 & \\
\hline $44 a$ & hypothetical protein & 5.4 & 9.1 & 38.5 & 54.5 & 152 & 31 & 7 & LOC_Os03g46100 \\
\hline $44 \mathrm{~b}$ & OsJ_13801 & 5.6 & & 38.0 & & 121 & 28 & 6 & \\
\hline $44 \mathrm{c}$ & & 5.7 & & 38.0 & & 139 & 33 & 6 & \\
\hline $44 \mathrm{~d}$ & & 7.3 & & 23.2 & & 80 & 19 & 5 & \\
\hline
\end{tabular}

${ }^{\mathrm{a}}$ Consistent with the spot numbers in Figure 2. ${ }^{\mathrm{b}} \mathrm{p} I$ Exp. is experimental isoelectric point, Theo. is theoretical isoelectric point. ${ }^{\mathrm{c}} \mathrm{Mr}(\mathrm{kDa})$ Exp. is experimental molecular size, Theo. is theoretical molecular size. ${ }^{\mathrm{d}}$ The protein score is $-10 * \log (\mathrm{P})$, where $\mathrm{P}$ is the probability that the observed match is a random event. Protein scores greater than 64 are significant $(p<0.05) .{ }^{e}$ Sequence coverage $(\%) .{ }^{\mathrm{f}}$ Number of matched peptides. ${ }^{\mathrm{g}}$ Accession number of the matched protein in the MSU Rice Genome Annotation (http://rice.plantbiology.msu.edu/). 